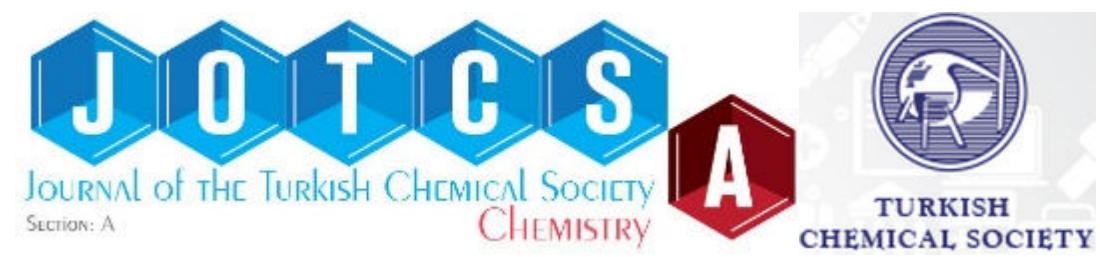

(This article was presented to the 28th National Chemistry Congress and submitted to JOTCSA as a full manuscript)

\title{
Synthesis and Characterization of Bio-Based Polyester Polyol
}

Tugba Yazici ${ }^{1,2}$ and Mithat Celebi ${ }^{1 *}$

\author{
${ }^{1}$ University of Yalova, Department of Polymer Engineering, 77100, Yalova, Turkey \\ ${ }^{2}$ Hürkimsa Chemical Industry, Çayirova, Kocaeli, Turkey
}

\begin{abstract}
Polyurethanes are versatile polymeric materials and are usually synthesized by isocyanate reactions with polyols. Polyurethanes have been used in very wide applications such as rigid and flexible foams, coatings, adhesives, and elastomers because of variety of polyols and isocyanates. Usage of bio-based resources has been increased due to limited petroleum resources, environmental concerns and ensuring sustainability. Polyester polyols are based on aliphatic and aromatic dicarboxylic acids are one of the most important materials in polymer technologies. Bio-based polyester polyols from renewable resources were successfully synthesized with different molecular weight at low acid value and desired hydroxyl value. In addition, the properties of the bio-based polyester polyols were compared with petroleum-based analogues.
\end{abstract}

Keywords: Polyester polyol; renewable resources; polyesterification.

Submitted: July 01, 2016. Revised: August 08, 2016. Accepted: November 19, 2016.

Cite this:Yazıcı T, Çelebi M. Synthesis and Characterization of Bio-Based Polyester Polyol. JOTCSA. 2016;3(3):721-30.

DOI: To be assigned.

*Corresponding author. E-mail: mithat.celebi@yalova.edu.tr. 


\section{INTRODUCTION}

Polyester polyols based on aliphatic and aromatic dicarboxylic acids are one of the most important materials in polymer technologies [1]. A large volume of plant oils is used as renewable resources to produce various chemicals which are industrially important to make soaps, cosmetic products, surfactants, lubricants, diluents, plasticizers, inks, agrochemicals, composite materials, and food industry [2]. Vegetable oils are one of the most important renewable resources in the chemical industry due to their biodegradability, availability, low-cost price, environmental acceptance, renewability, and non-toxic nature [3-8]. Vegetable oils and their derivatives have been widely used for the production of various polymers including polyols. Vegetable oil derivatives, such as fatty acids, fatty acid esters, and crude glycerol, can be obtained via hydrolysis or transesterification of vegetable oils [4]. Polyols and polyurethanes with properties comparable to those of petroleum-based analogs have been prepared from vegetable oils and their derivatives for various applications such as foams, coatings and adhesives, etc. [9-11].

Polyester polyols are the second most important group of oligo-polyols for the production of polyurethanes after polyether polyols. Polyester polyols have stable and specific practical applications due to some superior characteristics of the resulting polyurethanes [9]. The superior characteristics of polyester polyol based polyurethanes are explained by a better crystalline structure in the urethane segment, compared to the majority of polyether polyols which are amorphous, due to the superior secondary forces between the polyester chains and also due to a superior thermal and fire resistance, compared to polyether polyol based polyurethanes. Polyester based polyurethanes have a superior solvent resistance compared to the polyether-based polyurethanes. Polyester polyols were employed in both rigid and flexible polyurethane formulations $[6,10]$. The most important segments of polyester polyol applications are those of polyurethane elastomers, flexible foams, coatings, adhesives, rigid foams, synthetic leather, and sealants [1, 12].

In this work, production of polyester polyols was carried out by using dicarboxylic acids, diols, triols, and polyol from renewable resources with the presence of a catalyst. 


\section{MATERIALS AND METHODS}

Adipic acid (99\% pure; Acar Kimya, Turkey), phthalic anhydride (99\% pure; Acar Kimya, Turkey), terephthalic acid (99\% pure; Sigma-Aldrich, Turkey), ethylene glycol (99\% pure; Acar Kimya, Turkey), diethylene glycol (99\% pure; Acar Kimya, Turkey), trimethylolpropane (99\% pure; Sigma-Aldrich, Turkey), glycerol (99\% pure; Acar Kimya, Turkey) were used. Sorbitol was kindly obtained from Sunar Mısır, Turkey.

The dicarboxylic acids which are used to production of polyester polyols in this study were listed in Table 1.

Table 1: Main properties of used dicarboxylic acids.

\begin{tabular}{|c|c|c|c|}
\hline & $\begin{array}{l}\text { Adipic Acid } \\
\text { (AD) }\end{array}$ & $\begin{array}{l}\text { Phthalic anhydride } \\
\text { (PA) }\end{array}$ & $\begin{array}{l}\text { Terephthalic acid } \\
\text { (TPA) }\end{array}$ \\
\hline Appearance $\left(25^{\circ} \mathrm{C}\right)$ & White powder & White flakes & White crystals \\
\hline $\begin{array}{l}\text { Molecular Weight } \\
(\mathrm{g} / \mathrm{mol})\end{array}$ & 146.14 & 148.1 & 166.13 \\
\hline pH(of a solution) & $\begin{array}{l}3.2(0.1 \% \\
\text { solution })\end{array}$ & 2 (6 g/L aq. sol.) & - \\
\hline Density $\left(\mathrm{g} / \mathrm{cm}^{3}\right)$ & 1.360 & 1.53 & 1.522 \\
\hline $\begin{array}{l}\text { Melting point/Boiling } \\
\text { point }\left({ }^{\circ} \mathrm{C}\right)\end{array}$ & $152.1 / 337.5$ & 131.6 / 295 & 300 / decompose \\
\hline pH & $4.43 / 5.41$ & - & $3.51 / 4.82$ \\
\hline
\end{tabular}

Table 2: Main properties of the used glycols

\begin{tabular}{|c|c|c|c|c|c|}
\hline & $\begin{array}{l}\text { Ethylene } \\
\text { glycol(EG) }\end{array}$ & $\begin{array}{l}\text { Diethylen } \\
\text { e glycol } \\
\text { (DEG) }\end{array}$ & $\begin{array}{l}\text { Trimethyl } \\
\text { olpropane } \\
\text { (TMP) }\end{array}$ & Glycero & $\begin{array}{l}\text { Sorbitol } \\
\text { (ST) }\end{array}$ \\
\hline $\begin{array}{l}\text { Appearance } \\
\left(25^{\circ} \mathrm{C}\right)\end{array}$ & $\begin{array}{l}\text { Colorless } \\
\text { liquid }\end{array}$ & Liquid & $\begin{array}{l}\text { Colorless } \\
\text { solid }\end{array}$ & Liquid & $\begin{array}{l}\text { Crystalline } \\
\text { solid }\end{array}$ \\
\hline Functionality & 2 & 2 & 3 & 3 & 6 \\
\hline $\begin{array}{l}\text { Melting } \\
\text { Point/Boiling Point } \\
\left({ }^{\circ} \mathrm{C}\right)\end{array}$ & $-12.9 / 197.3$ & $\begin{array}{l}-10.45 / \\
244\end{array}$ & $58 / 285$ & $\begin{array}{l}18 \\
290\end{array}$ & 95 / 296 \\
\hline $\begin{array}{l}\text { Molecular Weight } \\
(\mathrm{g} / \mathrm{mol})\end{array}$ & 62.07 & 106.12 & 134.14 & 92.08 & 182.17 \\
\hline $\begin{array}{l}\text { Density } \\
\left(25^{\circ} \mathrm{C} \mathrm{g} / \mathrm{cm}^{3}\right)\end{array}$ & 1.1132 & 1.118 & 1.084 & 1.261 & 1.489 \\
\hline
\end{tabular}

\section{Synthesis of Bio-Based Polyester Polyols}

Commonly used diols and triols for production of polyester polyols were listed in Table 2 . Ethylene glycol and diethylene glycol which are bifunctional alcohols (glycols) were used in the synthesis of polyesters. Trifunctional ones, glycerol and trimethylolpropane were 
used. In addition, sorbitol from corn starch sources wasused in this work. Sorbitol polyol which is obtained from renewable resource contains 6 hydroxyl groups.

The direct polyesterification reaction was self-catalyzed by carboxyl groups of the acid reactants. However, due to the reduction of the concentration of these groups with increasing conversion, external catalysts were often used to maintain the rate of reaction. Stannous octoate and $\mathrm{p}$-toluene sulfonic acid catalysts were used in synthesis.

The excess of diol hasinfluence in final $M_{w}$ of polyester. Usually, in industry a $5-15 \%$ excess of diol is used.

The stoichiometric calculation;

$$
(\mathrm{n}+1) \mathrm{R}(\mathrm{OH})_{2}+\mathrm{n} \mathrm{R}^{\prime}(\mathrm{COOH})_{2} \longrightarrow \mathrm{HO}\left[\mathrm{ROOCR}^{\prime} \mathrm{COO}\right]_{n} \mathrm{ROH}+2 \mathrm{n} \mathrm{H}_{2} \mathrm{O} \text { (Eq. 1) }
$$

The stoichiometric ratio was $\mathrm{n}$ mol of diacid for $(n+1)$ mol of diol.

\section{Experimental apparatus}

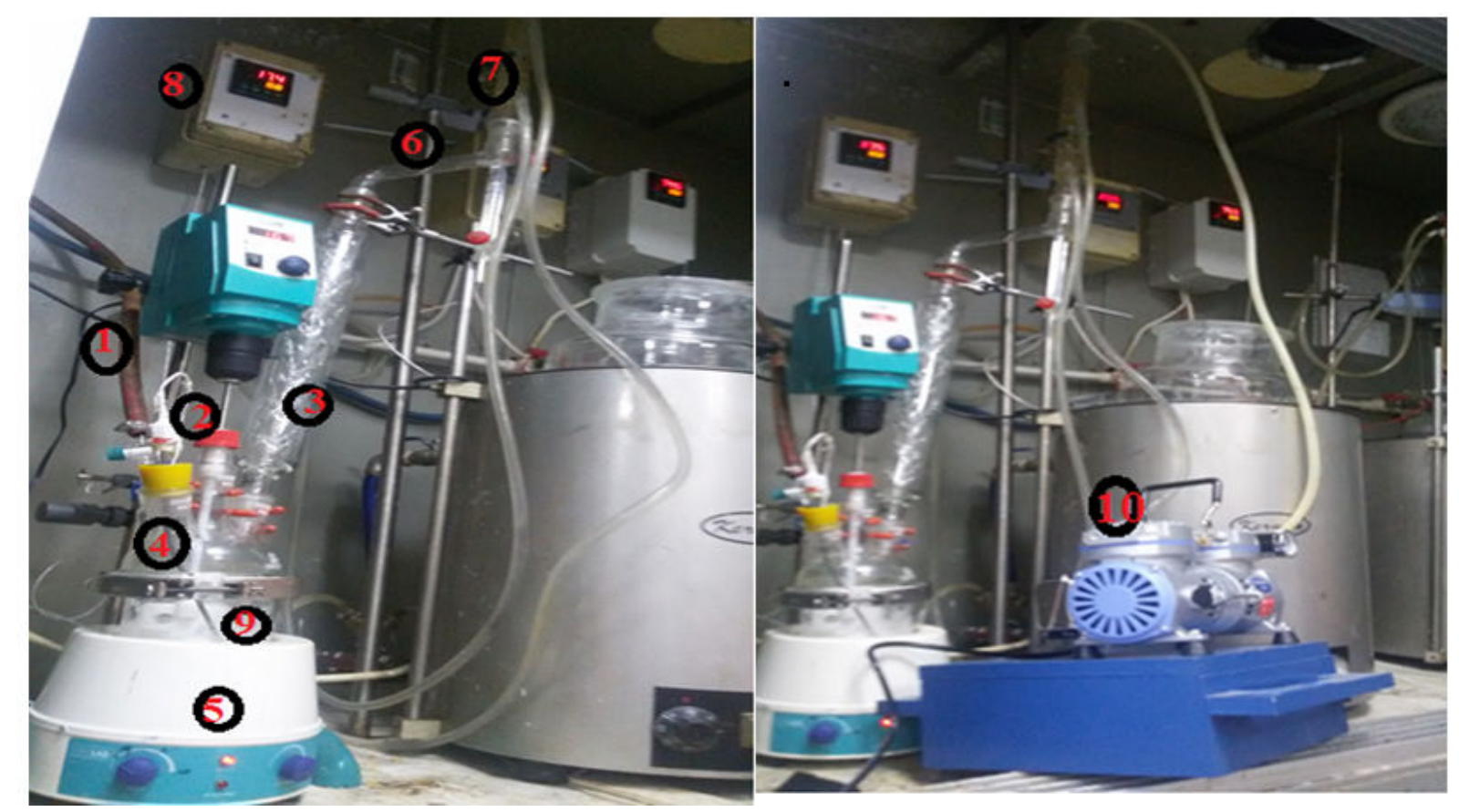

Figure 1: Set up equipment.

Set up equipment:1.Nitrogen spurge, 2.Stirrer, 3.Vigreux column, 4.Thermocouple, 5.Heating mantle, 6.Dean-Stark apparatus, 7.Condenser, 8.PID controller, 9.Threenecked round bottom flask, 10 . Vacuum pump. 


\section{Polycondensation}

To a three-necked reactor with a previously measured weight of dicarboxylic acid and glycol with PID controller set at $100^{\circ} \mathrm{C}$, constant stirring and under nitrogen atmosphere. The temperature was increased alternately from 140 to $220^{\circ} \mathrm{C}$ (at $140-160-180-200-220$ $\left.{ }^{\circ} \mathrm{C}\right)$. The reaction was very slow at low temperatures $\left(120-140^{\circ} \mathrm{C}\right)$. Therefore, the reflux of water was negligible at $120-140{ }^{\circ} \mathrm{C}$. The reflux of water was introduced at $170-180{ }^{\circ} \mathrm{C}$. When no further reflux of water was observed, a few grams of resin (1-2 g) should be taken in order to measure the acid number by titration with $0.1 \mathrm{~mol} / \mathrm{L}$ alcoholic solution of $\mathrm{KOH}$. When the acid number $\left(\mathrm{V}_{\mathrm{H}}\right)$ is lower than $3.0 \mathrm{mg} \mathrm{KOH} / \mathrm{g}$, the nitrogen flow should be increased. Vacuum can be applied to speed up the process. The acid number should be measured again and the synthesis is finished when $V_{H}$ is lower than 1.0 $\mathrm{mgKOH} / \mathrm{g}$ and hydroxyl value $\left(\mathrm{V}_{\mathrm{OH}}\right)$ is required. In parallel with the acid value $\left(\mathrm{V}_{\mathrm{H}}\right)$ analysis, hydroxyl value $\left(\mathrm{V}_{\mathrm{OH}}\right)$ should be also measured. For this 2-3 $\mathrm{g}$ of resin should be taken and the $\mathrm{V}_{\mathrm{OH}}$ was determined by titration with $0.5 \mathrm{~mol} / \mathrm{L}$ alcoholic solution of $\mathrm{KOH}$. The industrially used parameters to control the quality of the polyols are: appearance, color, hydroxyl number $\left(\mathrm{V}_{\mathrm{H}}\right)$, acid number $\left(\mathrm{V}_{\mathrm{OH}}\right)$, amount of water removed, $-\mathrm{MW}_{\mathrm{W}}$ Distribution, -Infrared Fourier Transform-Attenuated Total Reflectance Spectroscopy (FTIR-ATR), -viscosity and -density. Moreover, some of controlling parameters ( $\mathrm{V}_{\mathrm{H}}, \mathrm{V}_{\mathrm{OH}}$, $\mathrm{M}_{\mathrm{w}}$ ) should be calculated and checked during the whole reaction process.

\section{RESULTS AND DISCUSSION}

In this work, mainly the effects of reaction time, the amount of catalyst, reaction temperature, and the type of reactants and its ratio were investigated in the synthesis of polyesters. Percentage ratio moles of dicarboxylic acids, diols, triols, and renewable glycols used to each formulation were shown in Table 3. 
Table 3: Formulations of polyester polyol synthesis (mole \%) in this study.

\begin{tabular}{|c|c|c|c|c|c|c|c|c|}
\hline \multirow[b]{2}{*}{$\begin{array}{l}\text { Number of } \\
\text { Formulation }\end{array}$} & \multicolumn{3}{|c|}{ ACIDS } & \multicolumn{2}{|c|}{ DIOLS } & \multicolumn{2}{|c|}{ TRIOLS } & \multirow{2}{*}{$\begin{array}{l}\text { OTHER GLYCOLS } \\
\text { Sorbitol }\end{array}$} \\
\hline & AD & TPA & PA & EG & DEG & TMP & Glycerol & \\
\hline 1. & 0.63 & & & 1.26 & & & & \\
\hline 2. & 1.00 & & & & 1.92 & 0.08 & & \\
\hline 3. & 1.00 & & & & 1.98 & & & 0.02 \\
\hline 4. & & 0.36 & 0.22 & & 1.16 & & & \\
\hline 5. & & 0.56 & & & 1.00 & & 0.22 & \\
\hline 6. & & 0.25 & 0.15 & & 1.00 & & 0.11 & \\
\hline 7. & & 0.27 & 0.10 & & 1.00 & 0.11 & & \\
\hline 8. & & 0.33 & 0.13 & & 1.00 & & 0.29 & \\
\hline
\end{tabular}


Hydroxyl and acid numbers are indirectly proportional to polyesters' molecular weight. Table 4 represents the final acid and hydroxyl values obtained for eight syntheses.

Table 4: The results of acid value and hydroxyl value, molecular weight, amount of water distilled during process and density.

\begin{tabular}{|c|c|c|c|c|c|c|}
\hline $\begin{array}{l}\text { Number of } \\
\text { formulation }\end{array}$ & $\begin{array}{l}\text { Capacity } \\
\text { of reactor } \\
\text { (L) }\end{array}$ & $\begin{array}{l}\mathbf{V}_{\mathrm{H}} \\
{[\mathrm{mgKOH}} \\
/ \mathrm{g} \\
\text { polyol] }\end{array}$ & $\begin{array}{l}\text { VoH } \\
\text { [mgKOH } \\
\text { /g } \\
\text { polyol] }\end{array}$ & $\begin{array}{l}M_{w} \\
{[\mathrm{~g} / \mathrm{mol}]}\end{array}$ & $\begin{array}{l}\% \\
\text { Reflux } \\
\text { of water }\end{array}$ & $\begin{array}{l}\text { Density } \\
\left(\mathrm{g} / \mathrm{cm}^{3}\right)\end{array}$ \\
\hline 1. & 0.5 & 5.25 & 300 & 367.56 & 5.0 & 1.28 \\
\hline 2. & 0.5 & 5.95 & 350 & 472.82 & 5.6 & 1.18 \\
\hline 3. & 0.5 & 7.8 & 380 & 433.99 & 5.2 & 1.16 \\
\hline 4. & 0.5 & 5.6 & 250 & 438.97 & 5.5 & 1.23 \\
\hline 5. & 0.5 & 5.96 & 350 & 346.72 & 4.8 & 1.19 \\
\hline 6. & 0.5 & 7.2 & 315 & 383.05 & 5.6 & 1.19 \\
\hline 7. & 0.5 & 7.0 & 350 & 345.71 & 5.1 & 1.18 \\
\hline 8. & 0.5 & 6.9 & 350 & 377.24 & 5.2 & 1.20 \\
\hline
\end{tabular}

Figure 2 presents the typical behavior of the curves of acid number, hydroxyl number and $\mathrm{M}_{\mathrm{w}}$ over time for a produced polyol. The $\mathrm{M}_{\mathrm{w}}$ was calculated from the $\mathrm{V}_{\mathrm{H}}$ and $\mathrm{V}_{\mathrm{OH}}$.

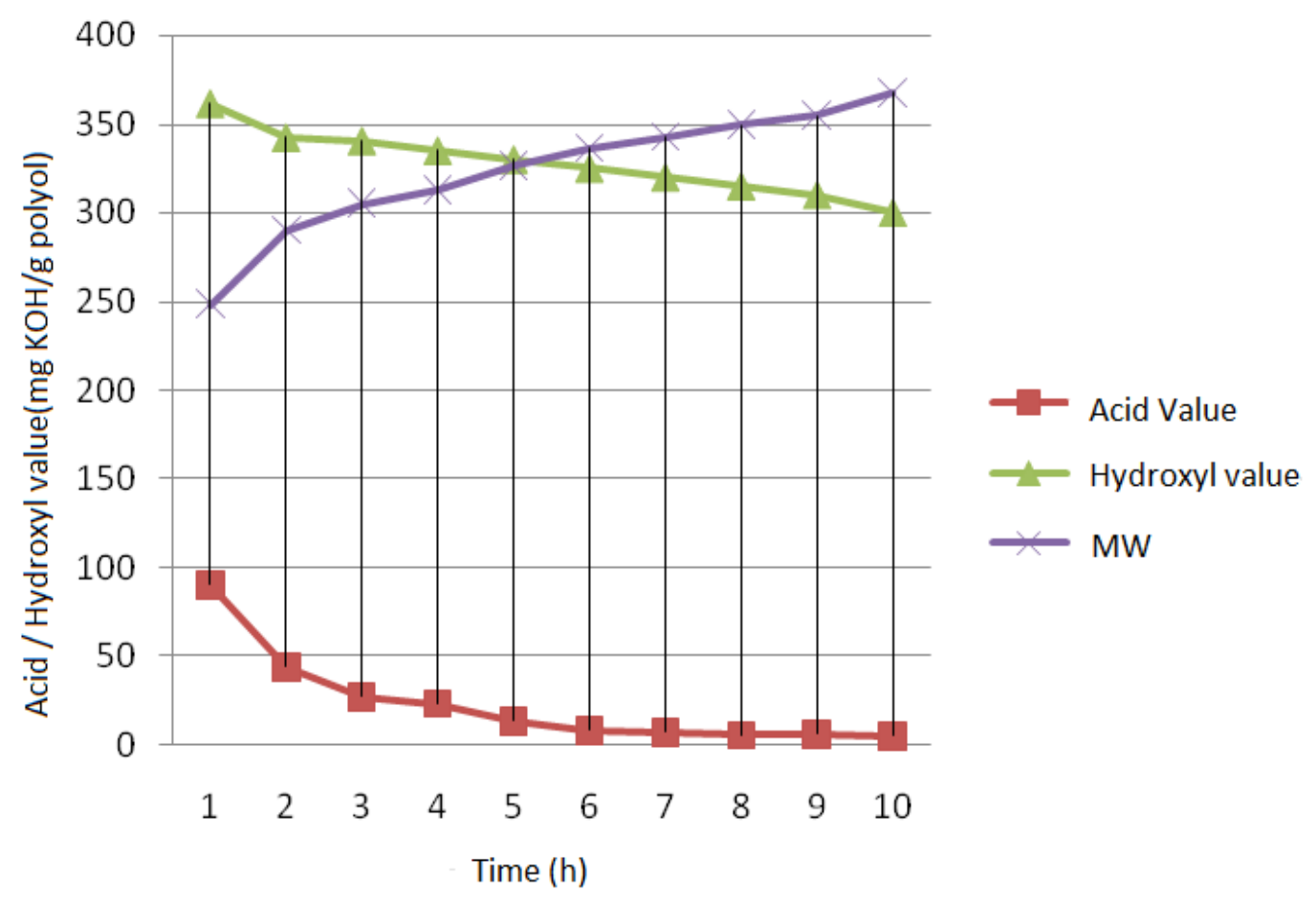

Figure 2: Number the fact of 1 formulation controlled medium values of $V_{H}, V_{O H}$ and $M_{W}$ over time. 
FTIR spectra of polyester polyol was presented in Figure 3.

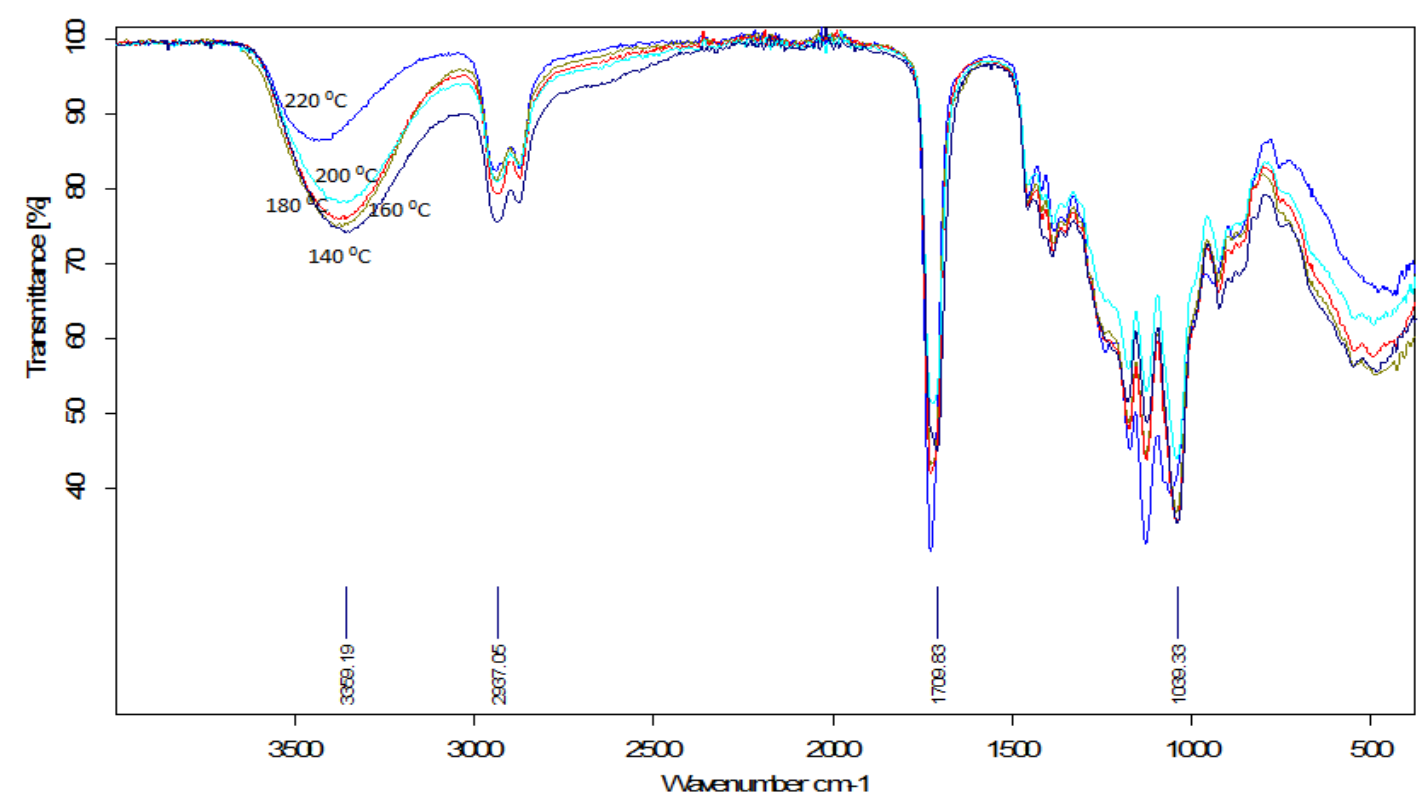

Figure 3: FTIR analysis of Number 1 formulation.

The peak at $1700 \mathrm{~cm}^{-1}$ corresponding to the $\mathrm{C}=\mathrm{O}$ stretch that was saturated carboxylic acid peak. The peak $2937 \mathrm{~cm}^{-1}$ was corresponding to the $\mathrm{C}-\mathrm{H}$ stretch. Also, the fact of hydroxyl band has high intensity-peak at near $3350 \mathrm{~cm}^{-1}$. High hydroxyl number polyester polyol were reached for rigid polyurethane. As the reaction temperature up to $220{ }^{\circ} \mathrm{C}$ from $140{ }^{\circ} \mathrm{C}$, the hydroxyl band formed high. This means that the reaction was completed.

The experimental part of this work involves the synthesis of saturated polyester polyols with petroleum glycols and biodegradable glycols. Sorbitol, which is a biodegradable and renewable polyol, has been produced from corn starch in Turkey. Different molecular weight polyester polyols were synthesized. However, the main goal of this study was to obtain saturated polyester polyols with high molecular weight. Polyesterification was confirmed via FTIR-ATR spectroscopy. Polyester polyols were synthesized successfully at low acid value and desired hydroxyl value.

\section{ACKNOWLEDGMENTS}

This study has been supported from Yalova University (BAP Project No: 2016/YL/70). 


\section{REFERENCES}

1. Ionescu, M. (2007). Chemistry and technology of polyols for polyurethanes. Polymer International (Vol. 56). DOI:10.1002/pi.2159.

2. Noreen A, Zia KM, Zuber M, Tabasum S, Zahoor AF. Bio-based polyurethane: An efficient and environment friendly coating systems: A review. Progress in Organic Coatings. 2016 Feb;91:25-32. DOI: 10.1016/j.porgcoat.2015.11.018.

3. Campanella, A., Rustoy, E., Baldessari, A., \&Baltans, M. A. (2010). Lubricants from chemically modified vegetable oils. Bioresource Technology, 101(1), 245-254. DOI: $10.1016 /$ j.biortech.2009.08.035.

4. Alagi, P., \& Hong, S. C. (2015). Vegetable oil-based polyols for sustainable polyurethanes. Macromolecular Research, pp. 1-8. DOI:10.1007/s13233-015-3154-6.

5. Desroches, M., Escouvois, M., Auvergne, R., Caillol, S., \&Boutevin, B. (2012). From Vegetable Oils to Polyurethanes: Synthetic Routes to Polyols and Main Industrial Products. Polymer Reviews, 52(1), 38-79. DOI:10.1080/15583724.2011.640443.

6. Pfister, D. P., Xia, Y., \&Larock, R. C. (2011). Recent advances in vegetable oil-based polyurethanes. Chem. Sus. Chem. DOI:10.1002/cssc.201000378.

7. Petrovic, Z. (2008). Polyurethanes from Vegetable Oils. Polymer Reviews, 48(1), 109-155. DOI: $10.1080 / 15583720701834224$.

8. Polyols, V. O. (2015). Feature Article, 23(12), 1079-1086. DOI:10.1007/s13233-015-31546.

9. Kadkin O, Osajda K, Kaszynski P, Barber TA. Polyester polyols: Synthesis and characterization of diethylene glycol terephthalate oligomers. Journal of Polymer Science Part A: Polymer Chemistry. 2003 Apr 15;41(8):1114-23. DOI: 10.1002/pola.10655.

10. Sonnenschein MF. Polyurethanes: science, technology, markets, and trends. Hoboken, New Jersey: Wiley; 2015. 417 p. ISBN: 978-1-118-73783-5.

11. Septevani, A. A., Evans, D. A. C., Chaleat, C., Martin, D. J., \&Annamalai, P. K. (2015). A systematic study substituting polyether polyol with palm kernel oil based polyester polyol in rigid polyurethane foam. Industrial Crops and Products, 66, 16-26.

DOI: $10.1016 /$ j.indcrop.2014.11.053

12. Ang, K. P., Lee, C. S., Cheng, S. F., \&Chuah, C. H. (2014). Synthesis of palm oil-based polyester polyol for polyurethane adhesive production. Journal of Applied Polymer Science, 131(6). doi:10.1002/app.39967 


\section{Türkçe Öz ve Anahtar Kelimeler}

\section{Biyo-Esaslı Poliester Poliolün Sentezi ve Karakterizasyonu}

Tugba Yazici ve Mithat Celebi

Öz: Poliüretanlar genellikle izosiyanatların poliollerle tepkimesi ile elde edilen çok yönlü polimerik malzemelerdir. Poliüretanlar, poliollerin ve izosiyanatların çeşitliliğinden dolayı sert ve esnek köpükler, kaplamalar, yapıştırıcılar ve elastomerler gibi çok çeşitli uygulamalarda kullanılmaktadırlar. Biyo-esaslı kaynakların kullanımı sınırlı petrol kaynakları, çevresel kaygılar ve sürdürülebilirliğin sağlanması nedeniyle artmaktadır. Alifatik ve aromatik dikarboksilli asitlere dayanan poliester polioller polimer teknolojisinde en önemli malzemelerden biridir. Yenilenebilir kaynaklardan üretilen biyo-esaslı poliester polioller, düşük asit değerinde ve istenen hidroksil değerine sahip olacak şekilde farklı moleküler ağırlıklarda başarı ile sentezlendi. Ek olarak, biyo-esaslı poliester poliolün özellikleri petrol esaslı benzerleri ile karşılaştırıldı.

Anahtar kelimeler: Poliester poliol; yenilenebilir kaynaklar; poliesterleşme.

Sunulma: 01 Temmuz 2016. Düzeltme: 08 Ağustos 2016. Kabul: 19 Kasım 2016. 